\title{
НАРАТИВНИЙ ПІДХІД ДО ПРОБЛЕМИ ІДЕНТИЧНОСТІ ОСОБИСТОСТІ В АНАЛІТИЧНІЙ ФІЛОСОФІї
}

\author{
О.Є. Оліфер
}

\begin{abstract}
Анотація. У статті розглянуто наративний підхід до проблеми ідентичності особистості в аналітичній філософії. Зазначено, що наративний підхід розвивається разом з нормативним на противагу онтологічному погляду на ідентичність. У статті визнається, що нормативний та наративний підходи схожі між собою, оскільки вони обидва розглядають ідентичність особистості як категорію, що грунтується на цінностях. Крім того, вони обидва розглядають особистість як суб'єкта діяльності, який усвідомлює свої дії. Проте наративний підхід відрізняється від нормативного. Наративний підхід поглиблює розуміння особистості як суб'єкта діяльності, додаючи, що особистість не лише усвідомлює свої вчинки і може приписати їх собі, але й визначає себе як суб'єкта діяльності. Увесь досвід, набутий особистістю, об'єднується в єдину послідовність подій - у наратив. Отже, він не тільки автобіографічна історія, але й спосіб буття особистості у часі. У статті розкрито такі основні риси наративу: правдоподібність, телеологічність, тематичний зв'язок між подіями, гнучкість, динамічність і соціальну природу. Зазначено, що ідентичність особистості - це єдність Я протягом часу. Отже, ця категорія витлумачується як така, що грунтується на практичних засадах. Створюючи автобіографічну історію, особистість усвідомлюе себе як унікальну істоту, яка залишається незмінною у часу. Наратив постає як єдина засада ідентичності особистості. У статті охарактеризовано процедуру ре ідентифікації, або характеризації, як механізм збереження ідентичності протягом часу. Отримуючи новий досвід, особистість синтезує його з попереднім. У такий спосіб ідентичність особистості відтворюється і зберігається протягом часу. Оскільки особистість може сформувати i підтримувати єдність свого Я лише в наративі, останній виступає єдиним критерієм ідентичності. У статті розглянуто зауваження, що висуваються до наративного підходу Дж. Девенпортом, Е. Руддом, Г. Стросоном та Д. Шумейкером. Усі аргументи, наведені проти наративного підходу, можна звести до таких: онтологічного, гносеологічного та практичного. Їх окреслено в останній частині статті.
\end{abstract}

Ключові слова: ідентичність, особистість, суб'єкт діяльності, наратив, реідентифікація. 


\title{
NARRATIVE APPROACH TO THE PROBLEM OF IDENTITY IN ANALYTICAL PHILOSOPHY
}

\begin{abstract}
The article considers the narrative approach to the problem of personal identity in analytic philosophy. It states that the narrative approach develops, together with the normative one, as opposed to the metaphysical view on identity. The article admits that the normative and narrative approaches are similar to each other, as they both consider personal identity as a category based on the values. Moreover, they both regard a person as an agent, conscious of their actions. Nevertheless, the narrative approach differs from the normative. The narrative approach deepens the understanding of a person as an agent, adding that a person is not only conscious of the actions and can attribute them to the self but also articulates being an agent. All experience gained by a person unites into a single succession of events - the narrative. Thus, it is not only an autobiographical story but also the way of a person being over time. The article reveals the main features of the narrative: plausibility, teleology, thematic connectedness between events, flexibility, dynamism, and its social nature. It states that personal identity is the unity of a person's self over time. So this category is treated as based on practical principles. Creating an autobiographical story, a person realizes themselves as a unique being, who remains the same over time. The narrative appears as the condition of personal identity. The article characterizes the procedure of re-identification or characterization as a mechanism of keeping identity over time. Gaining a new piece of experience, a person synthesizes it with the previous one. In such a way, personal identity reproduces and keeps over time. Since a person can create and maintain the unity of the self only in the narrative, the latter is the only criterion of identity. The paper also considers the critical remarks put forward to the narrative approach by J. Davenport, E. Rudd, G. Strawson, and D. Shoemaker. All arguments, introduced against the narrative approach, can be reduced to following: ontological, epistemological and practical. The final part of the article outlines them.
\end{abstract}

Keywords: identity, person, agent, narrative, re-identification.

\section{Вступ}

Будь-хто час від часу задається запитаннями: «Хто я?», «Що я роблю?», «Які мої цілі?». Звісно, у кожного будуть свої причини розмірковувати над ними, як і свої відповіді. Проте є дві риси, що об'єднують рефлексії подібного роду, - причина, чому людина замислюється над цим, і спосіб, як вона презентує результати власних розмислів. Причина полягає у тому, що людина відчуває свою тяглість у часі та брак сталих характеристик, що дають відчуття незмінності й прояву власної сутності. Тому вона неодноразово робить спробу приписати собі певні внутрішні властивості, наприклад, риси характеру, а також визначити зовнішні ознаки: належність до певної соціальної чи професійної спільноти. Усе це - спроба створити образ власного Я у часі або усвідомити власну ідентичність. Проте зрозуміти себе як істоту, що існує протягом певного часу, - це лише половина справи, оскільки ця ідея потребує певного вираження. Одиничні фрагменти реальності 
перетворюються у поняття, виражаються у словах, але певна послідовність досвіду різного роду вимагає вже більш складної форми вираження: окремі слова, що відображають одиничний досвід, об'єднуються в історію.

В аналітичній філософії зазначені проблема ідентичності особистості та її розгортання у часі як історії життя розглядаються в межах наративного напрямку, який виник порівняно нещодавно, у 1980-1990-х pр., і був розроблений у працях Д. Веллемана, К. Еткінза, А. Макінтайра, М. Шехтман та ін. Наразі наративний підхід є одним із трьох наявних в аналітичній філософії (поряд з онтологічним та нормативним), який актуалізує класичну для британської філософії проблему тотожності особистості, що була порушена ще Дж. Локком та його сучасниками. Проте наративний підхід - це не сучасна інтерпретація класичних концепцій, а, скоріш, спроба переосмислити класичну проблему та виробити нове розуміння тотожності особистості.

Варто зазначити, що наративні концепції не становлять однорідне явище. Наприклад, для А. Макінтайра наратив виступає як певний спосіб проілюструвати власну етичну концепцію. Д. Веллеман розглядає проблеми інтенційності діяльності та аксіології. К. Еткінз створює цілісну концепцію наративної тотожності, проте більше уваги звертає на проблеми вторинної рефлексії та утворення ідентичності внаслідок об'єднання різних психічних структур, що розгортаються у наративі. Найбільш розвинуту концепцію наративної ідентичності особистості презентувала М.Шехтман. Однак вона називає свій підхід поглядом щодо життя особистості (person life view). Уявлення про наративну ідентичність вона доповнюе аналізом життя особистості у межах суспільства та культури. Тобто її концепція найбільше наближена до соціальної філософії, але з використанням наративу як методу аналізу тотожності.

Наративний підхід, як і онтологічний та нормативний, розглядає три ключові запитання: (1) що таке ідентичність, (2) як вона формується (3) як ця ідентичність зберігається протягом часу. Далі ми висвітлимо зазначені пункти.

\section{1. Розгляд проблеми тотожності особистості в нара- тивному підході}

Наративне розуміння тотожності, відмінне від того, що окреслюється в концепціях нео-локкіанців С. Шумейкера, Дж. Перрі, Д. Парфіта та ін., розвиває М.Шехтман. Дослідниця відкидає думку про те, 
що тотожність особистості полягає у протяжності психічних процесів у часі $[14$, с. 18]. Особистість, порівнюючи себе зараз із собою в минулому, не може зробити об'єктивний висновок про свою тотожність: деякі моменти можуть переосмислюватися, забуватися. Деякі епізоди з дитинства взагалі не можна пригадати, для цього вже треба сформовану особистість. Крім того, виникає проблема так званої хибної пам'яті, коли особистість пригадує чиюсь дію як свою власну і приписує їі собі, хоча насправді вона лише спостерігала за нею. Хибна пам'ять виникає через специфіку пригадування [13, с.68]. Тож, простого пригадування себе в минулому і теперішньому недостатньо для обгрунтування ідентичності [14, с. 12$]$.

Тотожність особистості повинна стосуватися не лише минулого, але й майбутнього: особистість має бути впевнена, що сьогодні і завтра вона залишиться однією й тією ж особистістю. Однак психічна протяжність спрямована ретроспективно: пересвідчитися в тому, що особистість залишилася незмінною, можна тільки завдяки механізму пам'яті: якщо особа X пам'ятає свої минулі дії як власні й у теперішньому приписує їх собі, то це свідчить про збереження її ідентичності. Для обгрунтування тотожності з собою майбутнім в онтологічному підході застосовують концепцію однакового контенту свідомості, але М. Шехтман вважає, що оскільки «якісна ідентичність змісту свідомості є недостатньою, щоб зафіксувати те, що має відношення до особистої ідентичності» [16, с. $75-76]$.

На думку М. Шехтман, усі зауваження до критеріїв тотожності виникають через неправильне розуміння самої категорії ідентичності. В онтологічному підході тотожність розуміється як відношення між двома етапами у бутті особистості. Тобто особистість $x_{1}$ на проміжку часу $t_{1}$ буде визнана тією ж самою особистістю, що й особистість $x_{2}$ на проміжку часу $t_{2}$, якщо між особистостями на цих етапах наявне відношення типу рівності, що грунтується на однаковості свідомості між особистостями $x_{1}$ та $x_{2}$. Тобто, тотожність - це формально-логічне відношення між етапами розвитку особистості, що грунтується на протяжності психічних процесів. Як зазначає дослідниця, свідомість або протяжність психічних процесів взагалі неможливо аналізувати у формально-логічних термінах [15, с. 273]. Коли особистість думає про себе, вона не розглядає себе як сукупність темпоральних частин, між якими є відношення тотожності. Вона відчуває себе як цілісна істота, що зберігає себе як унікальну єдність певних рис і характеристик протягом часу (на цьому відчутті і повинна грунтуватися ідея тотожності), і при цьому намагається відшукати такі характеристики, що 
якнайкраще охарактеризують її якості та унікальність. Такий підхід М. Шехтман називає діахронічним холізмом [17, с. 7].

Д. Волков, аналізуючи концепцію М.Шехтман, звернув увагу на різницю в онтологічному та наративному підходах щодо тлумачення тотожності. Онтологічний підхід передбачає порівняння по суті двох повноцінних особистостей у різні моменти часу, між якими може бути встановлено відношення тотожності. Завдання філософів - довести або спростувати це, що означає обгрунтувати критерій, що є засадою тотожності між двома особистостями. Наративний підхід розглядає тотожність як відношення цілісної особистості до частини їі досвіду. Тобто в онтологічному підході особистість $x_{1}$ на проміжку часу $t_{1}$ та особистість $x_{2}$ на проміжку часу $t_{2}$-це дві різні особистості, тотожність яких треба довести або спростувати. У наративному - особистість в різні моменти часу залишається одна й кількісно незмінна, проте якісно відрізняється на різних етапах: особистість $x_{1}$ на проміжку часу $t_{1}$ та особистість $x_{2}$ на проміжку часу $t_{2}$ - це одна $\mathrm{i}$ та сама особистість, проте вона якісно різна за рахунок синтезування набутого досвіду з попереднім [1, с. 23-24]. Тобто наративна ідентичність особистості передбачає кількісну тотожність Я. Проте особистість якісно відрізняється від себе минулої, оскільки накопичує новий досвід.

М. Шехтман та Д. Шумейкер розглядають процес виникнення тотожності у діяльності через приписування особистістю досвіду, який вона переживає та усвідомлює. А. Макінтайр вважає, що життя особистості є занадто фрагментованим. Особистість виконує різні соціальні ролі, відповідно її Я постає як сукупність цих ролей [10, с. 204]. Залишити осторонь соціальну діяльність людини неможливо, тому необхідно відшукати спосіб інтеграції усіх досвідів у цілісність. А це і $є$ наратив, у межах якого формується та зберігається тотожність. Отже, наративний підхід розвиває тлумачення тотожності, що грунтується не на онтологічних, а на практичних засадах - на досвіді та діяльності.

Схоже розуміння тотожності як практичної категорії наявне в нормативному підході, зокрема у концепціях К. Корсгаард та К. Ровейн. Подібно до нього, наративні концепції приділяють значну увагу формуванню тотожності через процес атрибуції дії. Виконуючи дію, особистість усвідомлює її як свою власну і у такий спосіб приписує собі, себе вона розуміє як суб'єкта, який виконав цю дію. На думку М. Шехтман, свідченням успішної атрибуції є виникнення відчуття відповідальності $[17$, с. 14]. Нормативний підхід вбачає у цьому почутті прояв моральної природи особистості, що формує раціональну єдність Я. Наративний підхід розглядає відчуття відповідальності як свідчення того, що осо- 
бистість $є$ істотою протяжною у часі: вона пам'ятає про свій минулий досвід і цей досвід трансформує у цілі для подальшої діяльності.

Інша відмінність між нормативним та наративним підходами полягає у поясненні виникнення тотожності. Наприклад, у нормативній концепції К. Корсгаард під час виконання діяльності особистість формулює для себе нормативний принцип, через який розглядає власні мотиви. На його основі робиться висновок про те, чи варто виконувати діяльність [9, с. 100]. Цей принцип скеровує та об'єднує волю, і у такий спосіб нівелюються конфлікти між мотивами, та досягається цілісність Я. Цей нормативний принцип і є ідентичністю особистості $[9$, c. 120]. Отже, механізм привласнення дії суб'єкта є джерелом формування тотожності. Для наративного підходу важливим є те, що відбувається після усвідомлення приписування дії суб'єктом: як ця привласнена дія запам'ятовується, артикулюється і перетворюється у форму розповіді. Таке пояснення механізму атрибуції поєднує два важливі процеси у формуванні ідентичності: пам'ять та інтенційність.

Завдяки пам'яті особистість здатна до ретроспективної оцінки самої себе, що ймовірно стає можливим, якщо вона не лише усвідомлює дії, які виконує, а й певним чином поєднує їх у послідовну історію. Необхідність ретроспективи пояснюється тим, що коли особистість виконує дію, вона не завжди усвідомлює, який мотив спонукав виконати її у ситуації полімотивування або боротьби мотивів. Ретроспективний погляд дає можливість виявити додаткові мотиви діяльності і пояснити чому ця діяльність була виконана. Д. Веллеман зазначає, що запитання «Чому?» для особистості більш важливе, ніж сам факт виконання діяльності [22, с. 44]. Інтенційність дає змогу планувати діяльність, а у наративі - ще й довгострокову діяльність. Отже, наратив поєднує усі часові аспекти: минуле, теперішнє і майбутнє, створюючи континуум. Така інтеграція дозволяє особистості відчути власну протяжність, що для неї і $є$ вираженням тотожності самій собі. За словами K. Еткінза, якщо людина сприймає себе послідовною у часі, то це є одним із важливих механізмів конструювання її ідентичності. Аналізуючи минулі події, особистість підтверджує їх як свої власні, незалежно від того, схвалює вона їх чи ні. Тим самим вона формує відчуття власного Я, а потім проєктує його на майбутнє, ставлячи довгострокові цілі $[3$, с. 86 87]. Отже, у наративі особистість створює послідовну історію власної діяльності, синтезує розрізнений досвід із різних сфер і може екстраполювати його у майбутнє, усвідомлюючи своє життя як цілісність, протяжну у часі, а себе - автором наративу.

Це розв'язує проблему обгрунтування ідентичності особистості в 
майбутньому, що в класичних концепціях ідентичності була своєрідним каменем спотикання. Зокрема, для Локка і нео-локкіанців XX ст. це так і залишилося невирішеною проблемою, оскільки пам'яттю і навіть психічною протяжністю неможливо пояснити тотожність особистості самій собі у майбутньому. 3 іншого боку, включення теперішнього і минулого пояснюють, звідки в особистості виникає відчуття своєї тотожності у часі, що неможливо пояснити лише розглядаючи тотожність особистості зараз і у майбутньому.

М. Шехтман вважає, що проблема тотожності пов'язана у першу чергу зі збереженням відчуття сталості Я. Цю проблему вона називає реідентифікацією або характеризацією. На її думку, особистість протягом різних проміжків часу може проявляти різні свої риси з різною інтенсивністю, може виконувати різну діяльність та отримувати різний досвід. У такій ситуації вона повинна постійно переосмислювати своє життя, заново приписувати дії самій собі. У цьому і полягає сутність характеризації [17, с.99-100]. Д. Шумейкер конкретизує думку Шетхман, ставлячи питання про суть реідентифікації. На його думку, проблема реідентифікації формулюється так: що робить різні переживання, риси та дії такими, що вони приписуються одній людині та $\epsilon$ «частиною єдиної ідентичності, що становить наратив» $[18$, с. 6$]$. Тобто, переосмислюючи власний досвід, особистість пересвідчується у тому, що вона залишається ідентичною протягом часу, оскільки ре ідентифікація дає їй відчуття протяжності Я. Одночасно через переосмислення відбувається процедура відтворення власної ідентичності, оскільки різноманітний досвід заново синтезується у цілісність Я, з якою особистість пов'язує себе.

Така процедура можлива за умови, якщо досвід інтегрується у наратив. Тобто наратив є специфічним утворенням, осмисленням досвіду, в межах якого різний досвід об'єднується у цілісність, тобто тотожність, яка зберігається і постійно реконструюється протягом часу, коли до старого досвіду додається новий і ще раз переосмислюється. Тож, наратив є засадою ідентичності та методом збереження їі у часі.

Крім того, наратив $є$ способом буття особистості у часі. За словами М. Шехтман, наявність наративу є фундаментальною властивістю особистості, що відокремлює особистість від не-особистостей [17, с. 107]. На думку А. Макінтайра, тільки людина як особистість здатна бути автором наративу, тварини не можуть побудувати його [10, с. 208]. Тобто наратив - це фундаментальна здатність особистості, яка не може існувати інакше, ніж в межах наративу. У такій конструкції тотожність постає як сталість відчуття власного Я протягом часу. 


\section{2. Характеристики наративу}

Наратив відрізняється як від психічної протяжності процесів, яка розглядається в онтологічному підході, так і від звичайної послідовності подій чи історії. Наратив - це історія, що створена від першої особи. Тобто у наратив входить не будь-який досвід або спогади про будь-яку діяльність, а тільки автобіографічний досвід, тобто те, що є результатом діяльності особистості. Це убезпечує наратив від включення до нього хибних спогадів та інших ментальних станів подібного роду, коли особистість була лише свідком подій, але сприймала їх так, як ніби вона була безпосереднім учасником. Наявність погляду від першої особи одночасно є свідченням того, що в індивіда сформована свідомість та здатність до рефлексії, а отже, вона здатна сформувати власну ідентичність та усвідомлювати протяжність свого Я у часі. K. Еткінз навіть визначає тотожність як «загальне відчуття індивіда себе тим, хто він є з позиції першої особи» [3, с. 80].

Проте позиція першої особи може бути занадто суб'єктивною, що може спотворювати наратив і викривлювати інтерпретацію подій, що призведе до того, що наратив не буде взагалі відображати реальність. Тому важливою рисою наративу і вимогою до нього є правдоподібність. Р. Альтшулер вважає, що наратив повинен переосмислюватися, щоб було можливим віднайти рівновагу між позитивними і негативними сторонами життя, оскільки тоді життєва історія буде більш об'єктивною [2, с. 869]. К. Еткінз зазначає, що, окрім погляду від першої особи, у структурі Я особистості наявні також погляди від другої та від третьої осіб. Ці структури психіки утворюються під час розвитку та соціалізації особистості, коли вона взаємодіє з іншими і дивиться на себе через цю взаємодію, що відбувається завдяки здатності до вторинної рефлексії, яка дає змогу сприймати себе і як суб'єкт, і як об'єкт. Інтеграція цих психічних структур стає можливою у наративі, коли особистість інтерпретує свій довід та аналізує його через наративи інших людей. У такий спосіб у наративі формується узагальнений образ себе, що є наближеним до реальності [4, с. 45]. М. Шехтман зазначає, що наратив повинен бути визнаний іншими людьми як правдоподібний, щоб він мав здатність розвиватися, інакше його доведеться переосмислювати [17, с. 103].

Події у наративі пов'язані не лише причинно-наслідковим зв'язком, але ще й тематичним. На думку Дж. Крістмана, тематичність є найбільш гнучкою характеристикою наративу. Події систематизуються та групуються за певними темами, важливими для особистості. Це ро- 
бить наратив легко відтворюваним і захищає його від утворення певних «прогалин» у зв'язку між подіями, що виникає унаслідок забування. Загальна тема дозволяє об'єднати різні події в одну послідовність і зробити наратив зрозумілим, надає розрізненим подіям смислу та структурує життя [6, с. 705].

Наратив є з необхідністю телеологічним. Дж. Куллер вважає, що телеологічність наративу проявляється в тому, що, описуючи життя як розповідь, автор наративу надає життю сенс. Тобто сама форма розповіді уможливлює формулювання сенсу всієї структури $[7$, с. 82 83]. М. Шехтман вважає, що особистість сама формулює свої довгострокові цілі, коли усвідомлює своє життя як історію, обмежену у чаci $[17$, с. 112-113]. Е. Рудд зазначає, що особистість розглядається як суб'єкт діяльності, а будь-яка діяльність завжди має певну мету, якої треба досягти [11, с. 542]. Постійно виконуючи діяльність, особистість спрямовує зусилля на досягнення поставлених цілей. Наратив допомагає усвідомити цю мету. А. Макінтайр уявляє життя як квест або пошук, що спрямований до найвищого блага, що полягає в тому, як краще прожити життя [10, с. 218]. Телеологічна спрямованість наративу робить його динамічним та цілісним.

Осмислюючи своє життя як історію, особистість формулює для себе цінності. Д. Веллеман розрізняє цінності першого порядку й цінності другого порядку. Перші витлумачуються ним як ставлення до предметів, які задовольняють потреби. Філософ називає це тимчасовою вигодою. Цінності другого порядку надбудовуються над цінностями першого порядку. Щоб осмислити їх, необхідна наративна зв'язність подій та розгортання цінностей протягом часу. Д. Веллеман називає цінностями другого порядку соціальні цінності, наприклад, соціальну справедливість [23, с. 59].

Наратив являє собою інтерпретацію різного роду досвіду, яку особистість поєднує у форму історії. Тому важливою рисою наративу $є$ його зрозумілість для автора. Д. Веллеман називає наратив «жанром пояснення» $[21$, с. 1]. На думку дослідника, зрозумілість наративу забезпечується завдяки двом причинам. По-перше, самою природою оповідання: події, які утворюють наратив, мають форму історії, а будьяка історія містить сюжет: початок, розвиток дії, закінчення, передбачає дійових осіб, місце дії тощо. Структуровану подібним способом сукупність подій легше зрозуміти. По-друге, опис подій, які входять у наратив, повинен бути зрозумілим на рівні емоцій і почуттів, свідченням цього розуміння є емоційний відгук як у самого автора наративу, так і в його аудиторії [21, с. 18]. 
Наратив як «жанр пояснення» - гнучкий і динамічний. Його пластичність пов'язана з процедурою реідентифікації-постійним переосмисленням подій, узгодженням їх між собою, групуванням у теми. Динамічність є іншим боком процедури реідентифікації. Перегляд власного минулого спричинює зміну ставлення до теперішніх подій і запускає процес цілепокладання, спрямований на майбутнє. Події в наративі можуть бути переосмислені, наприклад, якщо особистість змінить ставлення до них. Проте історія повинна залишитися узгодженою та послідовною.

Наратив як історія життя від першої особи, у межах якої особистість зберігає відчуття протяжності Я у часі, включає не тільки події, але й думки, емоції, почуття, випадковості. Цей набір робить кожен конкретний наратив унікальним. Отже, наратив як засада ідентичності реалізує її у двох смислах. По-перше, ідентичність як цілісність і протяжність Я у часі. По-друге, як принцип розрізнення: наративна ідентичність є тим, що відрізняе одну особистість від іншої, обумовлюючи неповторність кожної.

Ще одна важлива характеристика наративу - його соціальність. А. Макінтайр називає соціальне середовище, в якому формувалася особистість, певним «місцем дії», з якого розгортається наратив [10, с. 206207]. Розуміння цього компоненту життєвого оповідання є важливим для того, щоб зрозуміти соціальні практики, у яких реалізує або буде реалізовувати себе особистість. Дослідник наголошує, що людина вже народжується з минулим: їі особистісна історія являє продовження історії того суспільства, в якому вона народилася. Протягом життя вона несе в собі історію спільноти, а відрізати це минуле означає деформувати теперішні відносини та стосунки особистості з іншими членами певного суспільства [10, с. 221]. Е. Рудд зазначає, що наратив як проєкт особистості самої себе є 3 необхідністю соціальним, тому що передбачає включення до різних соціальних інститутів: особистість планує одруження, виховання дітей, просування кар'єрною драбиною, участь у політичному житті країни [12, с. 429]. М. Шехтман називає таке залучення особистості до суспільства та культури - інфраструктурами особистості, що є необхідною основою, яка формує специфіку діяльності. До культурної інфраструктури дослідниця відносить освіту й те, що транслюється через освіту, наприклад традиції та світогляд. Соціальна інфраструктура - це приналежність до спільноти, у якій діють «інститути підтримки та влади» [17, с. 113-114]. Отже, наратив з необхідністю має соціальну природу. Без зв'язку з іншими особистість не здатна розвинути власну діяльність до такої стадії, щоб 
мати змогу будувати свій наратив. Соціальна взаємодія виступає тлом, на якому формуються довгострокові цілі особистості, унаслідок чого вона створює проєкт себе у майбутньому, що забезпечує телеологічну спрямованість та динамічність наративу. Зрештою, соціальна природа наративу забезпечує його правдоподібність: взаємодіючи з іншими, особистість вчиться ставити себе на їхне місце, таким чином вона переосмислює власне життя з позиції третьої особи, уникаючи викривлення наративу.

\section{3. Критика наративного підходу}

Загалом, наративний підхід розглядається як новий досить перспективний напрямок у розв'язанні проблеми ідентичності особистості. У ньому елімінуються проблеми, що загострювалися в класичних концепціях тотожності та в їхніх сучасних інтерпретаціях. Зокрема, це стосується проблеми порушення транзитивності ідентичності унаслідок забування або проблеми хибних спогадів, коли особа приймає дію, виконану іншим, за свою. У наративному підході інше розуміння ідентичності, тому проблема порушення тотожності внаслідок порушення транзитивності не розглядається. У наративі наявний тематичний зв'язок, який доповнює причинно-наслідковий, тому навіть якщо особистість забула певний епізод свого життя, це не руйнує цілісність ї̈ Я, а значить не порушує тотожність. Зникає також проблема множинності критеріїв тотожності, оскільки наратив є єдиною засадною виникнення й збереження тотожності. Проте філософи висувають ряд зауважень щодо наративного підходу. Із критикою виступають Г. Стросон, Д. Девенпорт, Д. Шумейкер, Е. Рудд та ін. Усі розглянуті ними аргументи проти наративу були об'єднані нами у такі групи: онтологічну, гносеологічну та практичну. Ці назви досить умовні, вживаються нами для відображення суті основної лінії критики.

До онтологічного аргументу можемо віднести уявний експеримент про діахроніків та епізодиків, розглянутий Г. Стросоном у статті «Проти наративу». Він виокремлює два типи особистостей, які відрізняються світоглядними установками. Діахроніки розглядають своє життя як цілісну історію, можуть прослідкувати, які події в минулому привели до певних наслідків. Епізодики розуміють життя як хаотичний набір подій, які жодним чином не пов'язані, не становлять собою цілісної історії. У їхньому житті події більше пояснюються випадковостями й тимчасовими бажаннями, ніж первинною минулою історією. 
Г. Стросон наголошує, що ті та інші - цілком звичайні люди, не мають жодних психічних чи фізичних проблем [20, с. 430]. Якщо вважати наратив універсальним способом буття особистості, то епізодиків не існувало б або це були б люди з певними психічними розладами. Наприклад, із синдромом множинної особистості. Однак епізодики існують. I вони точно є типом особистості. Позбавити їх цього статусу неможливо, оскільки вони свідомі, рефлексивні, здатні аналізувати виконану ними діяльність. Можна сказати, що якщо особа-епізодик сама не розуміє себе у межах наративу, це не означає що наративу не існує. Люди, що оточують епізодика, бачать розвиток його життя, зміну в етапах біографії, і можуть реконструювати наратив епізодика. Проте тоді уся концепція зводилася б до тривіальних речей, які утворювали б цей наратив. Наприклад, приготування кави, оскільки виконуючи цю повсякденну діяльність, ви повинні думати заздалегідь, робити справи в правильній послідовності [20, с. 439].

Дж. Девенпорт зазначає, що наратив не може бути тривіальним, оскільки в нього входять події, що мають значущість для людини. Однак, на його думку, у наративному підході недостатньо чітко витлумачується поняття наративу, не прояснюється, у чому полягає наративний зв'язок між подіями життя і як приписується значимість подіям у житті особистості, а без цих деталей наратив і перетворюється на банальність [8, с. 39].

Окрім того, Дж. Девенпорт зазначає, що наратив як протяжна у часі історія життя є процесом. В аналітичній філософії його слід розглядати з погляду чотиривимірної онтології. У певний момент часу наратив буде поставати як темпоральна частина, як відрізок усього наративу довжиною в життя. А частина не може проявляти усіх властивостей цілого. Тому в певний момент часу як наратив, так і особистість не можна зрозуміти як цілісність, а лише як частину цілого [8, c. 41].

Гносеологічний аргумент пов'язаний зі сприйняттям особистістю власного досвіду, що значно впливає на входження досвіду в наратив. Особистість тільки тоді вписує досвід у наратив, коли розглядає його від першої особи, усвідомлює і визнає як свій власний. Однак у житті людини є моменти, коли вона не може розглядати у такий спосіб своє життя: до-особистісна стадія у дитинстві, коли свідомість і самосвідомість ще не сформувалися; і після-особистісна стадія, коли особистість через травму мозку або психічну хворобу перестає усвідомлювати подіï, що з нею відбуваються як цілісну історію. Отже, наратив не збігається з життям [19, с. 97]. 
Інший важливий аргумент проти наративу пов'язаний з його надмірною суб'єктивністю та упередженістю. Д. Карр зазначає, що життя завжди складне й навіть дещо хаотичне, тому особистість не здатна охопити всі події в наратив, вона обирає, що включити в нього. Тому наратив являє собою штучно створену конструкцію, яка може виявитися суб'єктивною та упередженою [5, с. 10-11]. Дж. Девенпорт вважає, що біографії, хроніки й художня література $є$ артефактами, створеними людьми, тому вони є цілісними й існують в тому вигляді, в якому були створені. Наратив - одна інтерпретація життя з-поміж численних варіантів, яку людина обрала для себе й перетворила на історію, створивши такий умовний артефакт власного життя. Проте, обравши лише один варіант із множини, людина створює його цілісність, однак нехтує об'єктивністю [8, с. 39].

Е. Рудд зазначив, що недолік і навіть небезпека наративного підходу полягає в тому, що якщо визнати наратив способом концептуалізації досвіду в пізнанні, то такий досвід не можна ні верифікувати, ні фальсифікувати [12, с. 432]. Тобто наратив не можна взагалі перевірити на істинність.

Практичний аргумент проти наративного підходу був запропонований Д. Шумейкером. Він вважає, що оскільки наративний підхід грунтується на концепції практичної тотожності, то його слід використовувати для вирішення певних практичних проблем. Проте він не вирішує практичні аспекти реідентифікації. Наприклад, людина багато років не бачила свого знайомого, тому одного разу помилково прийняла іншого за нього. У такій ситуації судження про ідентичність особистості робиться на основі кількісної тотожності, що розглядається в онтологічному підході, а не наративу. Інший приклад стосується суджень від першої особи. Коли людина дивиться на свої дитячі фотографії вона впізнає себе і визнає, що ця дитина на світлині - це вона. Проте насправді не вписує досвід своїх дитячих років до наративу життя. Висновок, який вона робить про себе, грунтується виключно на кількісній ідентичності, оскільки особистість розуміє себе як кількісно незмінну у часі [19, с. 91-93].

\section{Висновки}

Отже, наратив постає у кількох смислах: (1) як метод формування тотожності, (2) спосіб її збереження у часі, (3) спосіб буття особистості у часі. Коли особистість усвідомлює свої виконані дії та приписує 
їх собі, вона упорядковує отриманий досвід у формі історії, а потім ототожнює своє життя з нею, а себе розглядає як автора та головного героя наративу. Особистість постає як сукупність різноманітних характеристик, набутих з досвіду, які не можуть повсякчас проявлятися з однаковою інтенсивністю. Тому час від часу необхідно здійснювати процедуру реідентифікації- перегляд свого досвіду, що дає їй впевненість у незмінності власного Я у часі. Звісно, така незмінність є досить умовною, оскільки тільки кількісно Я залишається незмінним, проте якісно змінюється за рахунок приєднання нового досвіду. Тобто ідентичність у наративі полягає в первинній інтеграції досвіду у Я, випрацюванні відчуття власної ідентичності у часі й подальше збереження кількісної тотожності Я.

Наратив як історія життя від першої особи характеризується правдоподібністю, телеологічністю, наявністю тематичного зв'язку між елементами досвіду, гнучкістю, динамічністю, зрозумілістю та соціальністю. У наративі формуються сенс життя та ціннісні ставлення до речей. 3 іншого боку, він може бути занадто суб'єктивним і не збігатися з життям: у наратив входять лише ті елементи досвіду, які особистість усвідомила та визнала своїми. У такому тлумаченні наратив постає скоріше як штучна конструкція, яку особистість створює для самої себе, щоб інтерпретувати різного роду досвід і пояснити його для себе. Тож, наративний підхід являє собою досить суперечливий напрямок у розв'язанні проблеми ідентичності. Зважаючи на його недоліки, він не може розглядатися як однозначна альтернатива онтологічному та нормативному підходам. Проблема ідентичності не знаходить однозначного вирішення в межах наративу, а значить пошуки альтернативних концепцій в аналітичній філософії будуть тривати.

\section{References}

[1] Volkov D.B. Narrativnyj podhod kak reshenie problemy tozhdestva // Vestnik SPbGU. - 2016. - Ser. 17. - Vyp. 4-S. 21-32.

[2] Altshuler $R$. Free will, narrative, and retroactive self-constitution // Phenomenology and the cognitive sciences. - 2015. - Vol. 14. No. 4 - P. 867-883. 
[3] Atkins K. Narrative identity and embodied continuity // Practical identity and narrative agency / ed. by Catriona Mackenzie and Kim Atkins. - New York: Routledge, 2008. - P. 78-98.

[4] Atkins K. Narrative identity and moral identity: A practical perspective. - New York: Routledge, 2008.

[5] Carr D. Time, narrative, and history. - Bloomington; Indianapolis: Indiana University Press, 1991.

[6] Christman J. Narrative unity as a condition of personhood Metaphilosophy. - 2004. - Vol. 35. - No. 5. - P. 695-713.

[7] Culler J. Literary theory: A very short introduction. - Oxford: Oxford University Press, 2000.

[8] Davenport J.J. Narrative identity, autonomy, and mortality: From Frankfurt and MacIntyre to Kierkegaard. - New York: Routledge, 2012.

[9] Korsgaard C. The sources of normativity / Christine M. Korsgaard, G. A. Cohen, R. Geuss, T. Nagel, B. Williams; ed. by Onora O'Neill. Cambridge: Cambridge University Press, 2010.

[10] Macintyre A. After virtue: A study in moral theory: 3rd edition. Notre Dame: University Of Notre Dame Press, 2007.

[11] Rudd A. Kierkegaard, MacIntyre and narrative unity - reply to Lippitt // Inquiry: An interdisciplinary journal of philosophy. - 2007. Vol. 50, No. 5. - P. 541-549.

[12] Rudd A. Narrative, expression and mental substance // Inquiry: An interdisciplinary journal of philosophy. - 2005. - Vol. 48, No. 5. P. 413-435.

[13] Schechtman M. Memory and identity // Philosophical studies: An international journal for philosophy in the analytic tradition.2011. - Vol. 153. - P. 65-79.

[14] Schechtman M. Personal identity and the past // Philosophy, psychiatry, and psychology. - 2005. - Vol. 12, No 1. - P. 9-22.

[15] Schechtman M. Personhood and the practical // Theoretical medicine and bioethics. - 2010. - Vol. 31, No. 4. - P. 271-283. 
[16] Schechtman M. Staying alive: Personal continuation and a life worth having // Practical identity and narrative agency // ed. by Catriona Mackenzie and Kim Atkins. - New York : Routledge, 2008. - P. 31-55.

[17] Schechtman M. Staying alive: Personal identity, practical concerns, and the unity of a life. - Oxford : Oxford University Press, 2014.

[18] Shoemaker D. Moral responsibility and the self // The Oxford Handbook of the Self / Shaun Gallagher (ed.). - Oxford : Oxford University Press, 2011. - P. 487-521.

[19] Shoemaker D. Personal identity and ethics: a brief introduction.Peterborough: Broadview Press, 2009.

[20] Strawson G. Against narrativity // Ratio. - 2004. - Vol.7, No.4.P. 428-452.

[21] Velleman D.J. Narrative explanation // The philosophical review. 2003. - Vol. 112, No. 1. - P. 1-25.

[22] Velleman D.J. Practical reflection // The philosophical review. 1985. - Vol. 94, No. 1. - P. 33-61.

[23] Velleman D.J. Well-being and time // Pacific philosophical quarterly. - 1991. - Vol. 72. - No. 1. - P. 48-77.

Надійшла до редакціӥ 31 липня 2020 р. 


\section{Оліфер Олена Євгеніївна}

Кафедра філософії

Криворізький державний педагогічний університет

просп. Гагаріна, 54

м. Кривий Ріг

50086

\section{Olifer Olena}

Department of Philosophy

Kryvyi Rih State Pedagogical University

Gagarina ave., 54

Kryvyi Rih

50086

iD https://orcid.org/0000-0002-8837-5514

@ olifer.olena@kdpu.edu.ua

doi $10.31812 /$ apd.v0i21.3880 